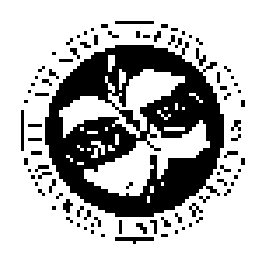

\title{
PARDUOTUVIŲ TINKLŲ PIRKĖJŲ SEGMENTAVIMAS PAGAL PIRKIMO PROGAS
}

\author{
Sigitas Urbonavičius ${ }^{1}$, Robertas Ivanauskas ${ }^{2}$ \\ ${ }^{1}$ Vilniaus universitetas, Sauletekio al. 9, LT-10222 Vilnius, Lietuva

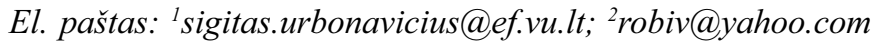

Iteikta 2005-10-14; priimta2005-12-01

\begin{abstract}
Santrauka. Intensyvi konkurencija tarp mažmeninès prekybos įmonių skatina geriau tenkinti pirkejjų poreikius. Todèl labai aktualūs tampa pirkèjų segmentavimo klausimai, siekiant išskirti tikslinį segmentą ir nustatyti jo poreikius bei reikalavimus. Tradiciniai demografiniai, geografiniai ir psichografiniai segmentavimo kriterijai gerai tinka tik segmentuojant santykiškai nedidelès ar siauriau specializuotos mažmeninès prekybos įmonès pirkèjus. Didelès mažmeninès prekybos įmonès ir parduotuvių tinklai teikia paslaugas daugybei pirkejų, kurie pasižymi įvairiomis socialinėmis, demografinėmis bei psichografinemis charakteristikomis. Šiuo atveju vien tradicinių išorinių segmentavimo kriterijų nebepakanka. Todèl straipsnyje nagrinëjami segmentavimo pagal pirkejjų elgseną klausimai. Tyrimų objektu pasirinkus parduotuvių tinklų pirkejjų elgseną, buvo siekiama ịvertinti tinklų pirkejjų segmentavimo pagal pirkimo progą (angl. buying occasion) galimybes. Tyrimų rezultatai atskleide, kad gali būti išskirtos tam tikros pirkimo progos, kurias galima apibūdinti ịsigyjamų prekių pobūdžiu, kiekiu ir apsipirkimo dažnumu, atspindinčios skirtingus pirkẻjų poreikius. Paprastai pirkèjai kiekvienai pirkimo progai renkasi geriausiai jas atitinkančias parduotuves, kurios gali skirtis savo tipu ir dydžiu. Tokios išvados leidžia kalbèti apie pirkèjo dalies (arba pirkejjo išlaidų dalies) koncepcijos taikymą parduotuvių tinklų pirkèjų elgsenai nagrinèti. Taigi parduotuvių tinklų pirkèjų segmentavimą pagal pirkimo progas galima laikyti veiksmingu, nors jis kol kas nėra naudojamas tinklų veikloje.
\end{abstract}

Pagrindiniai žodžiai: mažmeninė prekyba, parduotuvių tinklas, segmentavimas, diferenciacija, pirkimo proga, pirkėjo išlaidų dalis.

\section{SEGMENTATION OF MULTIPLE RETAILERS' CLIENTS ON THE BASIS OF SHOPPING OCCASIONS}

\author{
Sigitas Urbonavičius ${ }^{1}$, Robertas Ivanauskas ${ }^{2}$ \\ ${ }^{1}$ Vilnius University, Sauletekio al. 9, LT-10222 Vilnius, Lithuania

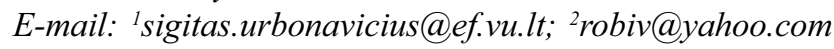

Received 14 October, 2005; accepted1 December, 2005.

\begin{abstract}
Rapid development of a retailing sector and the emergence of multiple retailers (also called chain stores or chains of stores) significantly increased the power of retailers over other members of products distribution channels. Large retailers, and especially chain stores become more and more independent from manufacturers and suppliers, take over the functions of wholesalers, make orders for manufacturing private label (or store brand) products, take part in product manufacturing processes. The implementation of modern information technologies enables multiple retailers to manage information about customers, their habits and demands of various products. The usage of this information allows multiple retailers to make a purposeful impact on customers' behaviour by using various marketing tools.

The development of retail companies and chain stores also increases competition among retailers themselves. Therefore retailers pay more attention to the analysis of competitors and search of new competitive strategies. Positioning concept is being implemented in retailing for assuring differentiation and positive opinion of customers. Besides that, intensive competition among retailers forces them striving to address customers' needs better. Therefore segmentation, targeting and evaluation of target segment(s) customers' needs and requirements become very important.

In case of multiple retailers, segmentation procedures are quite complicated because chain stores most often seek to serve the largest possible group of customers. Therefore traditional segmentation, based on demographic, geographic and psycho-
\end{abstract}


graphic criteria here is not fully suitable. For this reason more attention should be paid towards segmentation that is based on customer behaviour. This issue is not yet comprehensively analyzed and not many empirical surveys are performed yet.

This article analyses the possibilities to segment markets on the basis of shopping occasions. The analysis concentrates on customers of chain stores that are operating in Lithuania. Data were collected during two surveys. The first one was qualitative, and it included a set of in-depth interviews with customers. The second was quantitative and it was performed as a part of National Omnibus survey. Both surveys took place in July - August, 2004.

The research results allowed defining several typical shopping occasions. These shopping occasions can be characterized by the type of needed products, their quantity and shopping frequency. Depending on the specifics of the concrete needs at the moment, the same customers experience various needs and this triggers different shopping occasions. Then they relate specific shopping occasion with the types and brands of their known retail outlets. Customers were able to even name the chain stores, which in their opinion were the most suitable for a particular shopping occasion.

The fact that the majority of customers occurs in several buying occasions and prefers different stores allows concluding that a 'customer share' concept can be very much applicable in retailing. Supporting the idea of differentiation, this concept could help understanding, evaluating and satisfying customers' needs better. As a result, retailers can improve their overall competitive positions.

The results allow claiming that segmentation of multiple retailers' customers on the basis of shopping occasions is efficient and deserves more attention from managers of chain stores. It is important to further analyse the possibilities of segmentation according to shopping occasions in retailing, thus broadening traditional segmentation according to demographic, geographic and psychographic characteristics of retail customers. Possibly, the list of initially defined shopping occasions has to be expanded or changed. Finally, a similar survey of chain stores operating in the other retail sectors would help evaluate whether the concept is applicable under broader circumstances.

Keywords. Retailing, multiple retailer, segmentation, differentiation, shopping occasion, customer share.

\section{Ivadas}

Sparti mažmeninès prekybos plètra ir parduotuvių tinklų susiformavimas padidino mažmeninès prekybos įmonių itaką prekių paskirstymo kanaluose [1]. Didelès mažmeninès prekybos imonès ir ypač parduotuvių tinklai tampa vis labiau nepriklausomi nuo gamintojų ir tiekèjų, perima didmeninės prekybos įmonių funkcijas, teikia užsakymus gamybos įmonèms pagaminti tinklų firminiais ženklais pagamintas prekes, iš dalies dalyvauja prekių gamybos procesuose. Iddiegdami modernias informacines technologijas, parduotuvių tinklai valdo informaciją apie pirkèjus, jų ipročius, prekių paklausą. Naudodami šią informaciją tinklai ¿vairiomis marketingo priemonèmis daro kryptingą itaką pirkèjų elgsenai.

Mažmeninės prekybos vystymasis ir parduotuvių tinklų plètra ne tik keičia santykius tarp prekių paskirstymo kanalo dalyvių, bet ir didina mažmeninès prekybos įmonių konkurenciją. Daugelis mažmeninès prekybos sektorių pasižymi intensyvia konkurencija ir lètu augimu [2]. Popkowski, Peter, Sinha, Timmermans [3] netgi teigia, kad „,konkurencija mažmeninèje prekyboje pasiekè dramatišką lygmeni‘“ Dèl šios priežasties mažmeninès prekybos įmonėms tenka vis daugiau dėmesio skirti konkurentų analizei ir naujų konkuravimo būdų paieškai. Mažmeninès prekybos įmonès, siekdamos išsiskirti iš konkurentų, suformuoti palankią pirkèjų nuomonę ir užimti geresnes konkurencines pozicijas, pradeda taikyti pozicionavimo koncepcija.

Intensyvi konkurencija verčia mažmeninès prekybos imones stengtis geriau tenkinti pirkèjų poreikius. Todèl labai svarbu pirkejjus segmentuoti, pasirinkti tikslini segmentą ir įvertinti pirkejjų poreikius bei reikalavimus.

Kalbant apie didelių mažmeninès prekybos įmonių ir parduotuvių tinklus, segmentavimo procedūros gana prieštaringos, nes tinklai dažniausiai siekia teikti paslaugas kuo didesniam pirkèjų skaičiui. Tokiu atveju tradicinio segmentavimo (pagal demografinius, geografinius ir psichografinius pirkèjuc požymius) gali nepakakti. Todèl dèmesys vis dažniau kreipiamas i segmentavimą pagal pirkejjų elgseną. Šie klausimai kol kas nèra plačiai nagrinèti, atliekant pirkèjų elgsenos tyrimus. Lietuvoje mažmeninès prekybos imonių pirkèjų segmentavimo klausimai apskritai dar nebuvo pasirinkti mokslinių tyrimų objektu.

Šio straipsnio tikslas - apžvelgti pirkèjų segmentavimo galimybes, segmentavimo pagrindu pasirenkant pirkimo proga (angl. buying occasion). Pirkimo proga šiame straipsnyje vadinama specifinè situacija, kai pirkèjo poreikiams patenkinti reikalinga tam tikra mažmeninès prekybos paslauga ir kai pirkejjas priima sprendima, kokioje parduotuvejje jis gautu šiuos jo poreikius atitinkančią paslauga.

Straipsnyje aptariamų tyrimų objektas - parduotuviu tinklų (angl. multiple retailers arba chain stores) pirkejjų elgsena. Straipsnyje kalbama apie Lietuvoje veikiančius parduotuvių tinklus, parduodančius maisto prekes kartu su ivvairios paskirties ne maisto prekèmis.

Siekiant straipsnio tikslo, pirmiausia buvo aptarti segmentavimo mažmeninejje prekyboje ypatumai ir apžvelgti ankstesni šios srities tyrimai. Kitame skyriuje apibūdinami atlikti tyrimai ir nagrinejjamos hipotezès. Toliau aptariami tyrimų rezultatai: parduotuvių tinklų pirkejjų elgsenos ypatumai, renkantis parduotuvę, būdingiausios pirkimo progos. Be to, nagrinejjama, kaip skirtingi parduotuviu tinklai suteikia galimybę patenkinti tam tikras pirkimo progas. 


\section{Segmentavimo vieta marketingo strategijoje}

Formuojant įmonès strategija, numatoma, kokiais būdais bus siekiama patenkinti imonei keliamus tikslus. M. Porter [4] išskiria tris bendras strategines alternatyvas, kuriomis remiantis pasirenkama konkrečios įmonès strategija: 1) išlaidų lyderystè, 2) diferenciacija ir 3) fokusavimas. Išlaidų lyderystès atveju stengiamasi siekti kuo mažiausių prekių gamybos (arba paslaugų teikimo) ir paskirstymo išlaiduc, laikant juos visos konkuravimo strategijos pagrindu. Tačiau išlaidų lyderio vaidmuo sudetingas, nes konkuruojančios įmonès nuolat pasiūlo prekių arba paslaugų, kurių kainos gali būti dar mažesnès. Diferenciacijos strategijos esmè - konkurencine prasme skirtis nuo kitų imonių bei jų pasiūlymų. Diferencijuotis galima bet kurių vartotojams svarbių kriteriju pagrindu: remiantis ivvairiausiomis prekių ar paslaugų savybėmis, jų kainomis, personalo ar pardavimo kanalų savitumais ir t. t. [5]. Vienose šakose įmonėms plačių diferenciacijos galimybių teikia pats prekès ar rinkos pobūdis, kitose gana sunku aptikti net ir keletą diferenciacijos galimybių. Fokusavimo strategija naudojančios imonès sutelkia dèmesi i i nedideli rinkos segmentą. Dažnai koncentruojamasi ir ị itin specifinio poreikio tenkinimą siauros specializacijos pagrindu. Kitaip tariant, šią strategiją naudojančios i̇monès lyderystès arba diferenciacijos principus taiko itin nedidelei vartotojų grupei.

Kadangi ir vartotojų poreikių, ir jiems siūlomų prekių bei paslaugų ivvairovė nuolat didèja, efektyvių strategijų kūrimas dažniausiai pagrįstas rinkos segmentavimu. Jo pagrindu pasirenkama tiksline rinka (vienas ar keli tiksliniai rinkos segmentai), i kurios poreikių patenkinimą orientuojama įmonès marketingo veikla. Segmentavimas (heterogeniškos vartotojų visumos skaidymas i mažesnes homogeniškas grupes pagal pasirinktus požymius) ir tikslinès rinkos pasirinkimas yra pradiniai marketingo strategijos formavimo etapai [6]. Savo ruožtu tikslinès rinkos pasirinkimas sudaro prielaidas pozicionuoti - skirtingam nei konkurentų ivaizdžiui kurti vartotojų sąmonejje ir tinkamai konkurencinei pozicijai siekti.

Vartotojai turètų būti segmentuojami periodiškai, nes segmentai kinta. Siekiant atrasti naujų segmentų, naudinga atsižvelgti i vartotojų elgesio skirtumus, kai jie renkasi prekes ar paslaugas. Segmentavimas laikomas prasmingu, kai išskirtas tikslinis vartotojų segmentas gali būti išmatuojamas (dydis, perkamoji galia ir kt.), tinkamo dydžio, užtikrinantis reikiamas pajamas, pasiekiamas ir pasižymintis savita reakcija $\mathfrak{i}$ immonès naudojamas marketingo priemones.

Žinomi du apibendrinti segmentavimo variantai:

1. Segmentavimas pagal išorinius vartotojų bruožus.

2. Segmentavimas pagal vartotojų elgseną.

Pirmuoju atveju segmentuojama vertinant vartotojų geografines, demografines ar psichografines charakteristikas atspindinčius kriterijus, dažniausiai vienu metu naudojant keletą jų. Bene universaliausiais ir patogiausiais laikomi tipiški demografiniai kriterijai (lytis, amžius, pajamos), nes juos santykiškai lengva išmatuoti, o aptikti vartotojų elgesio pokyčius jų atžvilgiu taip pat palyginti nesunku.

Segmentuojant rinką pagal vartotojų elgsena, vartotojai skirstomi i grupes, remiantis jų žiniomis apie prekes ar paslaugas, požiūriais ir nuostatomis. Vartotojų elgsena gali būti analizuojama pagal ịvairius kriterijus: vartojimo progą (arba situacija), prekès ar paslaugos nauda, vartojimo dažnumą, vartotojų lojalumą ir daugeli kitų. Toks segmentavimas tiesiogiai siejamas su konkrečia preke ar paslauga, todèl kartais teigiama, kad būtent taip geriau pavyksta išskirti tikrai homogeniškus rinkos segmentus [7].

\section{Segmentavimas pagal vartotojų elgseną}

Pirmuoju atveju segmentuojama vertinant vartotojų geografines, demografines ar psichografines charakteristikas atspindinčius kriterijus, dažniausiai vienu metu naudojant keletą jų. Bene universaliausiais ir patogiausiais laikomi tipiški demografiniai kriterijai (lytis, amžius, pajamos), nes juos santykiškai lengva išmatuoti, o aptikti vartotojų elgesio pokyčius jų atžvilgiu taip pat palyginti nesunku.

Segmentuojant rinką pagal vartotojų elgsena, vartotojai skirstomi i grupes, remiantis jų žiniomis apie prekes ar paslaugas, požiūriais ir nuostatomis. Vartotojų elgsena gali būti analizuojama pagal ịvairius kriterijus: vartojimo progą (arba situacija), prekès ar paslaugos nauda, vartojimo dažnuma, vartotojų lojalumą ir daugelị kitų. Toks segmentavimas tiesiogiai siejamas su konkrečia preke ar paslauga, todèl kartais teigiama, kad būtent taip geriau pavyksta išskirti tikrai homogeniškus rinkos segmentus [7].

\section{Segmentavimo specifika mažmeninèje prekyboje}

Mažmeninės prekybos sektoriaus raida per pastaruosius kelis dešimtmečius buvo labai sparti. Vienu metu ryškejjo įvairios tendencijos: kooperavimasis ir koncentracija, diversifikacija ir specializacija, stiprejo internacionalizacija [8-11]. Mažmeninejje prekyboje diegiamos modernios informacinès technologijos. Jos didina darbo našuma, leidžia surinkti daug ivvairaus pobūdžio informacijos apie pirkejjus, pateikti jiems asmeninius pasiūlymus [11-13]. Formuojasi įvairūs mažmeninès prekybos įmonių junginiai (prekybos sistemos, grupès), vis didesni vaidmeni vaidina parduotuvių tinklai - mažmeninès prekybos įmonès, vykdančios veiklą ne vienoje, bet daugelyje parduotuvių, pavadintų tuo pačiu vardu.

Mažmeninès prekybos įmonès tapo svarbiausiais prekių paskirstymo kanalų dalyviais. Jos užtikrina ryši tarp gamintojų, tiekèjų ir galutinių vartotojų [12], jos gamintojus bei tiekèjus informuoja apie pirkèjų nusiskundimus, pageidavimus, prekių gražinimus. Mažmeninès prekybos įmonès pateikia gamintojams ir tiekèjams prekių pardavimo 
prognozes, numato prekių pristatymo terminus bei tvarką. Dèl šių priežasčių mažmeninès prekybos įmonès tampa vis labiau nepriklausomos nuo gamybos ir didmeninès prekybos įmonių. Mažmeninès prekybos įmonès ir ypač parduotuvių tinklai daro dideli poveikị ne tik mažmeninės prekybos raidai bei konkurencijos tarp prekybos imonių didejjimui, bet ir gamybos bei paslaugų imonių veiklai. Literatūroje nurodoma, kad būtent parduotuvių tinklų veiklos plètra nulèmė mažmeninès prekybos įmonių itakos prekių paskirstymo kanaluose didejjimą [14]. Parduotuvių tinklai neretai vykdo ne tik mažmeninès, bet ir didmeninès prekybos funkcijas. Gamybos ịmonès, parduodamos didelę dalị gaminamos produkcijos parduotuvių tinkluose, tampa labai priklausomos nuo jų ir konkuruoja su kitomis gamybos imonèmis dèl galimybès parduoti savo prekes tinklų parduotuvėse. Gamybos imonès tampa priklausomos nuo parduotuvių tinklų dar ir todèl, kad tinklai užsako gamybos imonèms pagaminti savo firminio ženklo prekes. Parduotuvių tinklai neretai ir tiesiogiai įsitraukia i gamybos procesa, kurdami prekes, nustatydami joms tam tikrus reikalavimus, tiekdami žaliavas, kontroliuodami gamybos procesa, prekių kokybę ir kitus svarbius rodiklius. Tinklai formuoja prekių pasiūlą, atsižvelgdami ị savo ilgalaikius tikslus ir santykius su gamintojais bei tiekejjais. Kartu tinklai gali tapti barjeru, neleidžiančiu kai kurių gamintojų prekèms pasiekti pirkèjus, ir prekių ìvairovė tinklų parduotuvèse tam tikra prasme ribojama [8]. Galiausiai parduotuvių tinklai, palyginti su kitomis mažmeninès prekybos įmonėmis, turi geresnių techninių ir finansinių galimybių kaupti bei analizuoti informaciją apie pirkejus ir įvairiomis marketingo priemonèmis daryti kryptingą itaką pirkèjų elgsenai.

Mažmeninès prekybos marketingo literatūroje išsakomos nuomonès, kad segmentavimo reikšmè mažmeninejje prekyboje yra kur kas mažesnè negu vartojimo prekių rinkose [15], kad segmentavimo nauda formuojant mažmeninès prekybos įmonès strategiją yra nedidelè [16]. Šios nuomonès grindžiamos tuo, jog mažmeninès prekybos įmonès dažnai konkuruoja dèl didžiausios galimos pirkèjų dalies, apimant visas pirkejjų grupes ir plačią kainų skalę. Taip pat teigiama, kad segmentuoti tinka tik tais atvejais, kai potencialūs pirkejjai kelia skirtingus reikalavimus mažmeninès prekybos įmonès teikiamoms paslaugoms. Jeigu tarp pirkèjų reikalavimų nėra didesnių skirtumų, įmonė gali išsiversti be segmentavimo ir orientavimosi i tikslines pirkejjų grupes [17].

Tačiau dauguma mažmeninès prekybos imonių laikosi marketingo orientacijos [10], pagal kurią imonès tikslų siekiama kuo geriau tenkinant pirkèjų poreikius. Tokiu atveju rinką segmentuoti ir tikslinio segmento pirkèjų poreikius nustatyti yra labai svarbu, siekiant pritaikyti įmonès teikiamas paslaugas prie pirkejjų poreikių, diferencijuoti įmonès pasiūlymą ir skatinti pirkti $[18,19]$. Pirkejjų poreikių ir reikalavimų analizè svarbi ir dèl intensyvios konkurenci- jos tarp mažmeninès prekybos įmonių. Konkuruoti plačiame rinkos segmente gali tik didelès įmonès, kurios naudojasi masto ekonomijos pranašumais, tačiau tokiu atveju mažejja jų išskirtinumas. Taigi rinką segmentuoti mažmeninèje prekyboje svarbu, tačiau praktiškai tai yra keblu naudoti dèl prekybos veiklos specifikos akivaizdžių savitumų.

Mažmeninėje prekyboje dažniausiai taikomi tradiciniai demografiniai, geografiniai ir psichografiniai rinkos segmentavimo kriterijai. Tačiau pastebèta, kad jie gerai tinka tik segmentuojant santykiškai nedidelès ar siauriau specializuotos mažmeninès prekybos įmonès pirkèjus. Didelès mažmeninès prekybos įmonès ir parduotuvių tinklai teikia paslaugas daugeliui pirkejjų, kurie yra įvairaus amžiaus, pajamų, vertybinių orientacijų, gyvenantys skirtingose geografinèse vietovėse. Prekybos įmonè realiai susiduria su daugybe subsegmentu, kurie nuolat persipina, nes jų atstovu požiūris i skirtingu grupių prekes nebūtinai sutampa. Be to, visi segmentavimo pagal išorinius vartotojo (pirkejjo) bruožus būdai tik netiesiogiai sietini su pačiu prekių pirkimo veiksmu. Todèl logiška ieškoti kitų segmentavimo alternatyvu.

Pagrindinė paieškos kryptis - segmentavimo pagal vartotojo (pirkejjo) elgseną galimybès, tinkamų pirkèjų elgsenos kriterijų paieška. Norint taip segmentuoti, reikia turèti informacijos apie pirkèjų elgsena, todèl tai yra santykiškai sudètingiau. Pradejjus vykdyti pirkèjų lojalumo programas, idiegus ivvairias pirkèjų korteles, reikiami duomenys apie pirkèjų elgseną tapo lengviau prieinami ir apdorojami. Atsirado galimybès sukurti pirkejjų tipologijos sistemas, kurios galètų būti naudojamos formuojant mažmeninès prekybos įmonès strategiją ir renkantis tinkamiausias marketingo priemones.

Nors segmentavimo mažmeninėje prekyboje problema yra aktuali, mokslinių publikacijų, kuriose būtų pateikiami segmentavimo tyrimų rezultatai, nėra daug. Steenkamp, Wedel [20] nagrinèjo šviežios mèsos pirkèjų segmentavimo galimybes, taikydami FCR analizès (angl. fuzzy clusterwise regression analysis) metoda. Gauti rezultatai atskleidè, kad šis analizès metodas leidžia sugrupuoti pirkèjus i tam tikrus segmentus ir nustatyti, kokie įvaizdžio požymiai svarbūs kiekvienam segmentui. Remiantis šiais rezultatais, galima formuoti marketingo strategija, orientuojantis i specifinius pasirinkto pirkejjų segmento poreikius. Webber [21] nagrinejjo vartotojų segmentavimo galimybes pagal ivvairias geografines-demografines vartotojų charakteristikas. Birtwistle, Clarke, Freathy [22] nagrinejjo drabužiu parduotuvių pirkèjų segmentavimo galimybes pagal pirkejjams svarbius parduotuvės požymius, remdamiesi tyrimų rezultatais, jog skirtingoms pirkèjų grupèms nagrinètų parduotuvės požymių svarba buvo nevienoda. Gonzalez-Benito [23] nagrinejjo Ispanijos hipermarketų tinklų potencialių pirkèjų geografines-demografines ir socialinesekonomines charakteristikas. Šių tyrimų rezultatai atskleidè atskirų hipermarketų tinklų pirkèjų struktūrą pagal ge- 
ografines-demografines charakteristikas. Socialinės-demografinės charakteristikos nesuteikè pagrindo paaiškinti, kodèl pasirenkami hipermarketų tinklai. Ziliani [24], naudodamasis pirkèjų lojalumo kortelèmis, nagrinejjo, kaip surinkta informacija naudojama maisto prekių pirkèjams segmentuoti Italijoje. Autore teigia, kad surinkta įvairi informacija apie pirkejjus gali būti panaudota sofistiniam segmentavimui ir mikromarketingui, tačiau mažmeninès prekybos imonès naudoja tik dali turimos informacijos. Ziliani, Bellini [25], remdamiesi vèlesniais tyrimais, teigia, kad segmentavimas ir tikslinio segmento pasirinkimas, remiantis lojalumo programų teikiama informacija apie pirkejus jų demografinę sudèti ir pirkimo elgseną, daro įtaką konkurencijai tarp mažmeninès prekybos įmonių ir mažmeninès prekybos imonių santykiams su gamintojais bei tiekèjais.

\section{Tyrimų metodika}

Ankstesni pirkèjų tyrimai atskleidè, kad parduotuvès pasirinkimas priklauso nuo pirkèjų elgsenos, kai jie jaučia vienokius arba kitokius poreikius, pavyzdžiui, pirkėjai renkasi vienokio tipo parduotuvę savaitgali, kai įsigyjami didesni prekių kiekiai, ir kitokio tipo parduotuvę, kai jiems reikia vieno ar kelių maisto prekių (duonos, pieno ir pan.) [26]. Tačiau tyrimai, kurių metu būtų nagrinejjami pagal pirkimo elgseną skirtingai pirkèjų segmentai, iki šiol buvo gana reti, nors praktine jų nauda sunku abejoti [27]. Šiuo straipsniu siekiama iš dalies užpildyti šią spraga, analizuojant iki šiol mažai nagrinètą pirkejjų segmentavimo pagal pirkimo progas varianta.

Tyrimo tikslas - įvertinti mažmeninès prekybos įmonès pirkèjų segmentavimo pagal pirkimo progas galimybes. Tyrimo objektu buvo pasirinkta Lietuvoje veikiančių parduotuvių tinklų, kuriuose parduodamos maisto ir įvairios paskirties ne maisto prekès (toliau tekste jie vadinami parduotuvių tinklais), pirkèjų elgsena. Tyrimo metu buvo siekiama patikrinti šias hipotezes:

H1: Nagrinèjant parduotuviu tinklu pirkejju elgsena, galima išskirti tam tikras pirkimo progas, perteikiančias skirtingus pirkeju poreikius.

H2: Parduotuviu tinklu teikiamos mažmeninès prekybos paslaugos sietinos ne tiek su tam tikrais pirkeju segmentais, kiek su pirkimo progomis, nes to paties pirkejo elgsena skiriasi, atsižvelgiant ì pirkimo proga.

Duomenys buvo surinkti atlikus du tyrimus. Pirmaji, kokybini, tyrimą sudarė išsamūs interviu su parduotuvių tinklų pirkėjais. Antraji, kiekybini, tyrimą sudare reprezentatyvi Lietuvos gyventojų apklausa. Išsamių interviu su pirkejjais metu surinkti duomenys buvo naudoti apklausos klausimynui parengti. Jie taip pat buvo naudojami ir apklausos rezultatams interpretuoti.

Išsamūs interviu su pirkejjais buvo atlikti $2004 \mathrm{~m}$. liepa ir rugpjūti. Jų metu buvo apklausta 17 respondentų, pasižyminčių skirtingomis socialinėmis-demografinėmis cha- rakteristikomis ir perkančių didesnę dali jų namų ūkiams reikalingų maisto ir ne maisto prekių. Šiu interviu metu buvo apklausti respondentai iš trijų didžiausių Lietuvos miestų - Vilniaus, Kauno ir Klaipėdos.

Reprezentatyvi Lietuvos gyventojų apklausa buvo atlikta 2004 m. rugpjūti kaip dalis nacionalinio „Omnibuso“ tyrimo, kuri atliko viešosios nuomonès ir rinkos tyrimų bendrovė „Baltijos tyrimai“. Apklausoje dalyvavo 1014 respondentų, kurių amžius siekè nuo 15 iki 74 metų. Tyrimų bendrovè užtikrino, kad tyrimo imties struktūra pagal įvairias socialines-demografines charakteristikas atitiktų Lietuvos gyventojų struktūrą pagal Statistikos departamento pateiktus duomenis.

Tyrimų metu surinkti duomenys buvo analizuojami naudojant SPSS 9.0 for Windows ir Microsoft Excel programines priemones. Analizès metu buvo skaičiuojami ir vertinami aprašomosios statistikos rodikliai.

\section{Parduotuvių tinklų pirkèjų elgsenos tyrimų rezultatai}

\subsection{Pirkimo progos}

Analizuojant išsamių interviu su parduotuvių tinklų pirkejjais duomenis, pastebèta, kad pirkèjai nurodo gana aiškiai apibrèžtas progas, kurioms susiklosčius jie vyksta i tinklų parduotuves pirkti pirmiausia maisto, o paskui ir įvairių ne maisto prekių. Apibendrinus duomenis, buvo išskirtos šios tipiškos pirkimo progos:

- Maisto prekių pirkimas nedideliais kiekiais, tačiau dažnai kasdien arba beveik kasdien.

- Maisto prekių pirkimas didesniais kiekiais kartą per savaitę ar per kelias savaites, kartu isigyjant ir ne maisto prekių (buitinès chemijos prekių, namų apyvokos reikmenų ir kt.).

- Paruoštų vartoti maisto gaminių, konditerijos gaminių, ivairių pusfabrikačių pirkimas.

- Aukščiausios kokybès, retų, prabangių maisto prekių pirkimas išskirtinėmis progomis (gimtadienio, švenčių ir pan.).

- Tam tikrų specifinių prekių pirkimas konkrečiame parduotuvių tinkle, specialiai vykstant $i$ to tinklo parduotuves, nes kituose parduotuvių tinkluose reikiamos prekès neparduodamos (pvz., tam tikro pavadinimo skalbimo milteliai, tam tikros rūšies vynas ir pan.).

- Drabužių ar avalynės pirkimas parduotuvių tinkluose, kartų isigyjant reikiamų maisto prekių.

Analizuojant išsamių interviu metu gautus duomenis, buvo pastebèta, kad pirkejjai pirmiausia savo norus bei poreikius susieja su tam tikra pirkimo proga, o paskui pasirenka ją geriausiai atitinkančią parduotuvę arba parduotuvių tinklą. Kiekvienas pirkèjas dažniausiai randa ne viena, bet kelias pirkimo progas. Jas geriausiai atitinka taip pat ne viena, bet kelios skirtingo tipo ir dydžio parduotuvès. Dèl šios priežasties pirkèjai nèra lojalūs tik vienai parduo- 
tuvei, o perka keliose mėgstamose parduotuvėse.

Reprezentatyvios Lietuvos gyventojų apklausos rezultatai patvirtino, kad tik nedidelę dali pirkèjų galima laikyti lojaliais vos vienai parduotuvei. Didžioji respondentų dalis $(63 \%)$ nurodè, kad jie perka keliose mègstamose parduotuvèse (žr. 1 lentelę).

Apklausos rezultatai taip pat patvirtino, kad pirkèjai dažniausiai turi pasirinkę kelias skirtingo tipo ir dydžio parduotuves, kuriose dažnai perka (žr. 2 lentelę).

2 lentelès pirmame stulpelyje nurodyta parduotuvè, kurioje nagrinėjama pirkèjų grupė perka dažniausiai, o antrame stulpelyje - parduotuvès, kuriose tie patys pirkèjai taip pat perka gana dažnai (remiantis jų pačių vertinimais). Šie lyginamieji duomenys rodo, kad pirkèjai, kurie dažniausiai perka mažų kainų parduotuvėse ,Saulute““, taip pat dažnai perka supermarketo tipo parduotuvėse „Iki“ bei „Maxima“ ir mažų kainų parduotuvėse „Norfa“ bei „Pigiau grybo“. Pirkèjai, kurie dažniausiai apsiperka supermarketo tipo parduotuvèse „Iki“, dažnai perka tiek supermarketo tipo parduotuvėse „Maxima“ arba „Rimi‘, tiek ir mažų kainų parduotuvėse „Saulute““ arba „Norfa“. Pirkejjai, kurie dažniausiai apsiperka kasdieninės paklausos (mišrių) prekių parduotuvèse (angl. convenience store) ,Minima“, dažnai apsipirkti renkasi mažų kainų parduotuves „Norfa“ arba „Saulute““ ir supermarketo tipo parduotuves „Iki“ arba

1 lentelè. Pirkejju ipročiai renkantis parduotuvę

Table 2. Customers' habits in store selection

\begin{tabular}{|l|c|}
\hline \multicolumn{1}{|c|}{ Pirkèjų ịpročiai } & Pirkejų dalis (\%) \\
\hline Perka tik vienoje parduotuveje & 15,7 \\
\hline $\begin{array}{l}\text { Dažniausiai perka vienoje } \\
\text { parduotuveje, bet kartais ir } \\
\text { kitose }\end{array}$ & 34,7 \\
\hline Perka keliose parduotuvėse & 28,1 \\
\hline Perka daugelyje parduotuvių & 12,0 \\
\hline Nežino, neatsake & 9,5 \\
\hline
\end{tabular}

2 lentelè. Pirkèjų lankomų parduotuvių lyginimas

Table 2. Comparison of favourite stores

\begin{tabular}{|c|c|}
\hline $\begin{array}{c}\text { Parduotuve, kurioje perka } \\
\text { dažniausiai }\end{array}$ & $\begin{array}{c}\text { Parduotuvès, kuriose taip pat } \\
\text { perka dažnai }\end{array}$ \\
\hline „Saulute““ & $\begin{array}{l}\text { „Iki“, „Norfa“, „Maxima“, } \\
\text { „Pigiau grybo“” }\end{array}$ \\
\hline „Norfa“ & $\begin{array}{l}\text { „Saulute““, „Maxima“, „Iki“, } \\
\text { „Pigiau grybo“ }\end{array}$ \\
\hline „Iki“ & $\begin{array}{l}\text { „Maxima“, „Saulute“, „Norfa“, } \\
\text { „Rimi““ }\end{array}$ \\
\hline „Maxima“ & $\begin{array}{l}\text { „Iki“, „Rimi“, „Norfa“, } \\
\text { „Saulute““ }\end{array}$ \\
\hline „Rimi“ & $\begin{array}{l}\text { „Iki“, „Maxima“, „Media“, } \\
\text { „Norfa“ }\end{array}$ \\
\hline „Minima“ & $\begin{array}{l}\text { „Norfa“, „Iki“, „Maxima“, } \\
\text { „Saulute““ }\end{array}$ \\
\hline „Pigiau grybo“ & „Saulute“", „Norfa“, „Media“ \\
\hline
\end{tabular}

„Maxima“. Iš to darytina išvada, kad pirkèjai ne tik nèra lojalūs vienai parduotuvei ar prekybos tinklui, bet, atsižvelgiant i pirkimo progas, renkasi ir skirtingo tipo parduotuves.

Taigi parduotuvių tinklų pirkėjų elgsena akivaizdžiai susijusi su tam tikromis pirkimo progomis, kurias galima ivvardyti ir apibūdinti, nurodant isigyjamų prekių pobūdị, kiekị bei apsipirkimo dažni. Pirkejjai susieja savo poreikius su pirkimo progomis ir renkasi vieną iš kelių mėgstamų parduotuvių, kuri geriausiai tinka tai pirkimo progai. Atsižvelgiant $\mathfrak{i}$ šiuos rezultatus, galima patvirtinti pirmaja hipotezę - nagrinejjant parduotuviu tinklu pirkejju elgsena, galima išskirti tam tikras pirkimo progas, perteikiančias skirtingus pirkeju poreikius.

\subsection{Parduotuvių tinklų tinkamumas tam tikroms pirkimo progoms}

Išsamių interviu metu pirkëjai išsakè nuomones, kad kiekvienai jų poreikius atitinkančiai pirkimo progai tinkamiausia būna viena iš jų mėgstamų parduotuvių. Dėl šios priežasties apklausos metu pirkejjų buvo prašoma nurodyti, kokios parduotuvès geriausiai tiktų tam tikrai pirkimo progai (žr. 3 lentelę).

Pirkèjų nuomone, dažnai pirkti maisto prekes nedideliais kiekiais tinka įvairaus dydžio bei tipo parduotuvès. Tai galima paaiškinti atstumo iki artimiausios parduotuvès ir patogumo itaka - šia pirkimo proga parduotuvès pasirenkamos pagal tokius kriterijus. Pasirenkamos parduotuvès paprastai būna arčiausiai pirkejjų namų ar darboviečių arba pakeliui iš darbo i namus.

Maisto ir ne maisto prekèms pirkti didesniais kiekiais

3 lentelè. Parduotuvių tinklų tinkamumo įvairioms pirkimo progoms iqvertinimas

Table 3. Correspondence of chain stores to various shopping occasions

\begin{tabular}{|c|c|}
\hline Pirkimo proga & $\begin{array}{c}\text { Tinkamiausi parduotuvių } \\
\text { tinklai }\end{array}$ \\
\hline $\begin{array}{l}\text { Maisto prekių pirkimas } \\
\text { nedideliais kiekiais dažnai }\end{array}$ & $\begin{array}{l}\text { „Saulute““, „Norfa“, „Iki““, } \\
\text { „Pigiau grybo“, „Minima“ }\end{array}$ \\
\hline $\begin{array}{l}\text { Maisto ir ne maisto prekių } \\
\text { pirkimas didesniais kiekiais } \\
\text { rečiau }\end{array}$ & $\begin{array}{l}\text { „Maxima“, „Hyper Rimi“, } \\
\text { „Iki““, „Norfa“ }\end{array}$ \\
\hline $\begin{array}{l}\text { Paruoštų vartoti maisto } \\
\text { gaminių ir pusfabrikačių } \\
\text { ịsigijimas }\end{array}$ & „Maxima“, „Iki“ \\
\hline $\begin{array}{l}\text { Aukščiausios kokybės, retų, } \\
\text { prabangių maisto prekių } \\
\text { pirkimas }\end{array}$ & „Maxima“, „Iki“, „Hyper Rimi“ \\
\hline $\begin{array}{l}\text { Drabužiu ir avalynès pirkimas, } \\
\text { kartu įsigyjant maisto prekių }\end{array}$ & „Maxima“, „Hyper Rimi“ \\
\hline $\begin{array}{l}\text { Tam tikrų prekių pirkimas, } \\
\text { specialiai vykstant i konkretaus } \\
\text { tinklo parduotuves (nes } \\
\text { kituose tinkluose tų prekių } \\
\text { nėra) }\end{array}$ & „Maxima“, „Hyper Rimi“ \\
\hline
\end{tabular}


ir rečiau dažniausiai pasirenkamos didelès, supermarketo arba hipermarketo tipo parduotuves. „Iki“ ir „Norfa“ parduotuvès buvo nurodytos tinkamomis abiem pirkimo progomis pirkti (ir nedideliais, ir didesniais kiekiais) todèl, kad šių vardų parduotuvės yra įvairaus dydžio (pvz., ,,Norfa“" parduotuviu plotas kinta nuo $200 \mathrm{~m}^{2}$ iki daugiau kaip $\left.2000 \mathrm{~m}^{2}\right)$.

Pirkèjai labiausiai vertina „Maxima“ ir „Iki“ parduotuvių tinkluose pagamintus maisto gaminius bei pusfabrikačius. Aukščiausios kokybès, retas maisto prekes pirkejjai labiausiai linkę pirkti ne tik „Maxima“ bei „Iki“, bet ir „Hyper Rimi“" parduotuvėse. $\mathrm{Na}$, o drabužius bei avalynę ir tam tikras specifines prekes pirkèjai linkę pirkti tik didžiausiose parduotuvėse. Atsižvelgiant $i$ šiuos rezultatus, galima patvirtinti antrają hipotezę - parduotuviu tinklu teikiamos mažmeninès prekybos paslaugos sietinos ne tiek su tam tikrais pirkèju segmentais, kiek su pirkimo progomis, nes to paties pirkèjo elgsena skiriasi, atsižvelgiant ì pirkimo proga.

Atliktų tyrimų rezultatai leidžia kalbėti apie pirkėjo dalies (angl. customer share) koncepcijos [7] pritaikymą mažmeninëje prekyboje maisto prekemis. Remiantis šia koncepcija, mažmeninès prekybos i̇monè turètų sutelkti dèmesị ne tik ị rinkos dalị, bet ir ị pirkejjo dalị, o dar tiksliau sakant - i pirkejjo išlaidų dalị, tenkančią konkrečiai mažmeninès prekybos įmonei. Remiantis atliktų tyrimų rezultatais, galima teigti, kad parduotuvių tinklų pirkèjų segmentai iš dalies sutampa, t. y. tas pats asmuo yra ir „Iki“, ir „Maxima“, ir galbūt dar kurio nors kito parduotuvių tinklo pirkejjas. Šis pirkèjas pasirenka „Iki““ parduotuvę viena pirkimo proga, o „Maxima“ parduotuvę - kita proga. Gali būti, kad „Iki” parduotuvė bus pasirinkta maisto prekèms pirkti nedideliais kiekiais kasdien ir paruoštiems vartoti maisto gaminiams pirkti, o „Maxima“ parduotuvè - maisto prekèms įsigyti dideliais kiekiais. Taip apsiperkama savaitgaliais arba kas porą savaičių, kartu perkant ir reikalingas ne maisto prekes. Žinant, kokia pirkimo proga pasirenkamas „Iki“" parduotuvių tinklas ir kokia proga - „Maxima“ tinklas, galima prognozuoti, kokia pirkèjo išlaidų dalis tenka vienam ir kitam tinklui.

Pirkejjų segmentavimo pagal pirkimo progas ir pirkèjo dalies (arba pirkejjo išlaidų dalies) koncepcijos suderinimas parduotuvių tinklams padètų tiksliau įvertinti pirkejjų poreikius bei lūkesčius ir geriau juos patenkinti, suteikiant jiems tokią mažmeninès prekybos paslauga, kokios jie tikisi. Tai savo ruožtu padètų padidinti pirkejjų išlaidų dali, tenkančią parduotuvių tinklui. Galiausiai geriau nustatyti ir patenkinti pirkèjų poreikiai užtikrintu palankią pirkèjų nuomonę apie parduotuvių tinkla, padidintu jo išskirtinumą ir pagerintų konkurencinę poziciją.

\section{Išvados ir tolesnių tyrimų kryptys}

Segmentuoti mažmeninès prekybos įmonių pirkèjus pagal socialines, demografines ir psichografines charakteristikas ne visada efektyvu, siekiant nustatyti tikslini rinkos segmentą ir jo poreikius. Todèl daugiau dėmesio reikètú skirti segmentavimo pagal pirkèjų elgseną klausimams, kurie kol kas nèra plačiai nagrinèti.

Tyrimai, kurių metu buvo analizuojama parduotuvių tinklų pirkèjų elgsena, atskleidè, kad gali būti išskirtos tam tikros pirkimo progos, rodančios skirtingus pirkejjų poreikius. Pirkimo progas galima apibūdinti pagal prekių pobūdị, kiekị ir apsipirkimo dažni. Pvz., skirtingomis progomis laikytinas maisto prekių pirkimas nedideliais kiekiais dažnai ir maisto prekių pirkimas didesniais kiekiais rečiau, toje pačioje parduotuvèje issigyjant ir ne maisto prekių.

Parduotuvių tinklų pirkejjų elgsenos ypatumai išryškèja keliomis tipinėmis, daugeliui pirkèjų būdingomis pirkimo progomis. Atitinkamai dauguma pirkèjų turi ne viena, o kelias mègstamas parduotuves, kurios dažnai būna skirtingo dydžio ir tipo. Pirkèjai susieja savo poreikius su konkrečia pirkimo proga, o paskui renkasi vieną iš kelių mėgstamų, tai progai geriausiai tinkančių parduotuvių.

Parduotuvių tinklų pirkèjų elgsenos tyrimų rezultatai leidžia teigti, kad pirkėjų požiūriu skirtingų vardų parduotuvių tinklai tinka skirtingoms pirkimo situacijoms.

Tyrimų rezultatai, atskleidžiantys, kad pirkèjų elgsenai būdingos kelios pirkimo situacijos ir kad pirkejjai dažniausiai turi kelias mėgstamas parduotuves, leidžia kalbėti apie pirkèjo dalies (arba pirkèjo išlaidų dalies) koncepcijos pritaikyma, analizuojant parduotuvių tinklų pirkèjų elgseną. Jos taikymas gali padèti geriau ivertinti pirkejuc poreikius ir tinkamai juos patenkinti, padidinant parduotuvių tinklo išskirtinumą ir pagerinant konkurencinę poziciją.

Taigi, remiantis atliktų tyrimų rezultatais, galima teigti, kad parduotuvių tinklų pirkèjų segmentavimas pagal pirkimo progas yra veiksmingas. Tačiau tinklai kol kas neakcentuoja šio rinkos segmentavimo būdo. Autorių nuomone, segmentavimas pagal pirkimo progas leistų parduotuvių tinklams geriau pritaikyti teikiamas paslaugas prie pirkejjų poreikių ir pasiekti ryškesni išskirtinuma.

Kalbant apie tolesnių tyrimų kryptis, pirmiausia reikètų pabrèžti, kad atlikti parduotuvių tinklų pirkèjų elgsenos tyrimai yra tik pirkejų segmentavimo pagal pirkimo progas klausimų nagrinėjimo pradžia. Todẻl tyrimų rezultatus reikètų laikyti pradiniais, skirtais ateityje nagrinètinus klausimus tiksliau suformuoti ir geriau pasirengti tolesniems tyrimams.

Straipsnio autorių nuomone, tolesni šios srities tyrimai turètų būti pirmiausia nukreipti i parduotuvių tinklų pirkèjų segmentavimo modelio sudarymą ir segmentavimo pagal pirkimo progas bei pagal išorinius pirkèju požymius suderinimo galimybių nagrinejjimą. Atliekant tolesnius tyrimus taip pat galima būtų patikrinti, ar išskirtų pirkimo situacijų sąrašas yra baigtinis, ar turi būti praplèstas ir patikslintas. Taip pat galima būtų ivertinti, kokie parduotuvès požymiai svarbūs pirkejjams skirtingomis pirkimo progomis. Tai padètu geriau suprasti, kodèl, esant tam tikrai progai, vienos parduotuvès pirkejjams atrodo tinkamesnès 
negu kitos. Be to, tai būtų naudinga nustatant, kaip susiformuoja kelių pirkejjo mėgstamiausių parduotuvių rinkinys. Galiausiai galima būtų atlikti analogiškus tyrimus, tyrimų objektu pasirinkus kito mažmeninès prekybos sektoriaus parduotuvių tinklus. Tai padètų ivertinti, ar pirkèjų segmentavimas pirkimo progu pagrindu tinkamas visoms mažmeninès prekybos įmonėms, ar tik tam tikro mažmeninės prekybos sektoriaus įmonèms.

\section{Literatūra}

1. Bell, R. Competition issues in European grocery retailing. European Retail Digest, Issue 39, 2002, p. 27-37.

2. Kristensen, K.; Juhl, H. J.; Ostergaard, P. Customer satisfaction: some results for European retailing. Total Quality Management, Vol 12, No 7\&8, 2001, p. 890-897.

3. Popkowski, L.; Peter, T. L.; Sinha, A.; Timmermans, H. Consumer store choice dynamics: an analysis of the competitive market structure for grocery stores. Journal of Retailing, Vol 76, 2000, p. 14-28.

4. Porter, M. Competitive Strategy: Techniques for Analyzing Industries and Competitors. New York: The Free Press, 1980. $115 \mathrm{p}$.

5. Kotler, P. \& Keller, K. L. Marketing management. 12th edition. Upper Saddle River, New Jersey: Pearson Education, Inc., 2006. 729 p.

6. Kotler, P.; Armstrong, G.; Saunders, J.; Wong, V. Principles of Marketing. Third European Edition. Harlow: Pearson Education, Ltd., 2001. 834 p.

7. Kotler, P. Marketing management. Eleventh edition. New Jersey: Pearson Education, Inc., 2003. 706 p.

8. Gilbert, D. Retail Marketing Management. Harlow: Pearson Education Limited, 2003. 457 p.

9. Newman, A. J.; Cullen, P. Retailing: Environment \& Operations. London: Thomson Learning, 2002. 496 p.

10. Omar, O. Retail Marketing. London: Financial Times \& Pitman Publishing, 1999. 448 p.

11. Pajuodis, A. Prekybos marketingas. Vilnius: Eugrimas, 2002. $347 \mathrm{p}$.

12. Berman, B.; Evans, J. R. Retail Management. A Strategic Approach. Eight Edition. New Jersey: Prentice-Hall, Inc., 2001. $708 \mathrm{p}$.

13. Sullivan, M.; Adcock, D. Retail Marketing. London: Thompson, 2002. 350 p.

Sigitas URBONAVIČIUS. Dr., Assoc Prof Marketing Departmet of Faculty of Economics of Vilnius University. Research interests: marketing strategies, positioning, small and medium business specifics. The main scientific results: author/co-author of 5 books, numerous methodological publications, conferece thesis and articles in academic journals.

Robertas IVANAUSKAS. Doctoral student Business Department of Faculty of Economics at Vilnius University. Fields of scientific interests: retail marketing, positioning in retailing. The main scientific results: four publications in reviewed academic journals, which analyze positioning in retailing and Lithuanian SMEs development.
14. McGoldrick, P. J. Retail Marketing. Second Edition. Maidenhead: McGraw-Hill Education, 2002. 658 p.

15. Wileman, A.; Jary; M. Retail Power Plays: From Trading to Brand Leadership. London: Macmillan Press Ltd., 1997. $280 \mathrm{p}$.

16. Davies G.; Brooks, J. Positioning strategy in retailing. London: Paul Chapman Publishing, 1989. 228 p.

17. Mattmüller, R.; Tunder, R. Strategisches Handelsmarketing. München: Verlag Franz Vahlen, 2004. 506 p.

18. Taylor, S. L.; Cosenza, R. M. Profiling later aged female teens: mall shopping behaviour and clothing choice. Journal of Consumer Marketing, Vol 19, No 5, 2002, p. 393-408.

19. Sullivan, P.; Savitt, R.; Zheng, Y.; Cui, Y. Rural shoppers: who gets their apparel dollars? Journal of Fashion Marketing and Management, Vol 6, No 4, 2002, p. 363-380.

20. Steenkamp, J.-B. E. M.; Wedel, M. Segmenting retail markets on store image using a consumer-based methodology. Journal of Retailing, Vol 67, No 3, 1991, p. 300-320.

21. Webber, R. EuroMosaic: the emergence of multinational micro-marketing. European Retail Digest, 1994, p. 9-15.

22. Birtwistle, G.; Clarke, I.; Freathy, P. Customer decision making in fasion retailing: a segmentation analysis. International Journal of Retail \& Distribution Management, Vol 26, No 4, 1998, p. 147-154.

23. Gonzalez-Benito, O. Geodemographic and socioeconomic characterization of the retail attraction of leading hypermarket chains in Spain. The International Review of Retail, Distribution and Consumer Research, Vol 12, No 1, January 2002, p. 81-103.

24. Ziliani, C. Sophisticated segmentation and precise targeting: loyalty cards in Italy. European Retail Digest, Issue 39, 2002, p. $47-50$.

25. Ziliani, C.; Bellini, S. Retail micro-marketing strategies and competition. The International Review of Retail, Distribution and Consumer Research, Vol 14, No 1, January 2004, p. 7 18.

26. Uusitalo, O. Consumer perceptions of grocery retail formats and brands. International Journal of Retail \& Distribution Management, Vol 29, No 5, 2001, p. 214-225.

27. Boedeker, M. New-type and traditional shoppers: a comparison of two major consumer groups. International Journal of Retail \& Distribution Management, Vol 23, No 3, 1995, p. 17-26. 